\section{Air pollution and hospital admissions for respiratory diseases in the subequatorial Amazon: a time series approach}

\author{
Poluição do ar e admissões hospitalares por \\ doenças respiratórias na Amazônia subequatorial: \\ abordagem de séries temporais
}

Eliane Ignotti 1,2

Sandra de Souza Hacon 3 Washington Leite Junger 4

Dennys Mourão ${ }^{3}$

Karla Longo 5

Saulo Freitas 6

Paulo Artaxo 7

Antônio Carlos Monteiro Ponce de Leon 4
1 Universidade do Estado de Mato Grosso, Cáceres, Brasil. 2 Instituto de Saúde Coletiva, Universidade Federal de Mato Grosso, Cuiabá, Brasil. 3 Escola Nacional de Saúde Pública Sergio Arouca,

Fundação Oswaldo Cruz, Rio de Janeiro, Brasil.

4 Instituto de Medicina Social, Universidade do Estado do Rio de Janeiro, Rio de Janeiro, Brasil.

5 Centro de Ciência do Sistema Terrestre, Instituto Nacional de Pesquisas Espaciais, São José dos Campos, Brasil.

6 Centro de Previsão de Tempo e Estudos Climáticos, Instituto Nacional de Pesquisas Espaciais, Cachoeira Paulista, Brasil. 7 Instituto de Física, Universidade de São Paulo, São Paulo, Brasil.

Correspondence E. Ignotti Universidade do Estado de Mato Grosso. Av. Tancredo Neves 1095, Cáceres, $M T$ 78200-000, Brasil. eliane.ignotti@pq.cnpq.br

\section{Abstract}

The objective of the study is to evaluate the effect of the daily variation in concentrations of fine particulate matter (diameter less than 2.5 $\mu \mathrm{m}$ $P M_{2.5}$ ) resulting from the burning of biomass on the daily number of hospitalizations of children and elderly people for respiratory diseases, in Alta Floresta and Tangará da Serra in the Brazilian Amazon in 2005. This is an ecological time series study that uses data on daily number of hospitalizations of children and the elderly for respiratory diseases, and estimated concentration of $P M_{2.5}$. In Alta Floresta, the percentage increases in the relative risk (\%RR) of hospitalization for respiratory diseases in children were significant for the whole year and for the dry season with 3-4 day lags. In the dry season these measurements reach 6\% (95\% CI: 1.4-10.8). The associations were significant for moving averages of 3-5 days. The \%RR for the elderly was significant for the current day of the drought, with a $6.8 \%$ increase (95\%CI: 0.513.5) for each additional $10 \mu \mathrm{g} / \mathrm{m}^{3}$ of $\mathrm{PM}_{2.5}$. No associations were verified for Tangara da Serra. The $P M_{2.5}$ from the burning of biomass increased hospitalizations for respiratory diseases in children and the elderly.

Respiratory Tract Diseases; Hospitalization; Air Pollution

\section{Introduction}

In the Amazon and Central regions of Brazil, thousands of fires with smoke clouds covering millions of square kilometers break out during the dry season, (which typically lasts from June to October), and are detected every year by satellite (Centro de Previsão de Tempo e Estudos Climáticos, Instituto Nacional de Pesquisas Espaciais. http://www.cptec.inpe.br). Almost all the fires are man made and are started for distinct reasons: for selling wood, clearing pastures, preparing the land for crops, manual harvesting of sugarcane, and as a result of land disputes 1 . Among the states which constitute the Brazilian Amazon, Mato Grosso had the highest concentration of heat outbreaks (36\%) and of deforested area (38\%) in the period 2000 to 20062 .

There are no doubts that air pollution has a negative impact on human health. Of all the health effects related to air pollution, respiratory diseases are the most significant, especially amongst vulnerable groups like children and the elderly 3,4. Epidemiological studies address both the short and long-term health effects of exposure to particulate matter suspended in air and gaseous contaminants, however the latter are scarce. Further, most of the studies refer to population groups living in metropolitan areas exposed to air pollution formed by emissions from industries and/or intense road traffic 5,6,7,8,9,10. 
In the subequatorial Amazon, air pollution studies as a result of fires began in 1998 (Programa de Grande Escala da Biosfera-Atmosfera na Amazônia. http://lba.cptec.inpe.br/lba/ site/), but it was only in 2007 that the first findings suggesting an association between the surrounding air and respiratory diseases were published 11,12,13.

The emission of air pollutants in the Amazon is not homogeneously distributed. Conversely it is concentrated along the so-called "deforestation arc", which covers Southeastern Maranhão state, Northern Tocantins, Southern Pará, Northern Mato Grosso, Rondônia, Southern Amazonas and Southeastern Acre, accounting for over $85 \%$ of the fires that occur in Brazil during the regional dry season 14 . During this period, concentrations of particulate matter with an aerodynamic diameter of less than $2.5 \mu \mathrm{m}$, originating from the burning of biomass vary from 300 to $600 \mu \mathrm{g} / \mathrm{m}^{3}$ at the sites where the fires are most intense 15 .

Any particulate with a diameter measuring less than $2.5 \mu \mathrm{m}\left(\mathrm{PM}_{2.5}\right)$ is recognized as a threat to human health as well as a cause of reduced life expectancy 16 . These particulates, known as fine particles, represent $60 \%$ of the particulate matter produced by the burning of biomass in the Amazon 17 and are potentially poisonous because they deeply penetrate the lung tissues from where they can unleash a series of health effects due to their physical, chemical, toxicological and/or carcinogenic nature 18,19 . In spite of this, studies of the effects of emissions derived from the burning of biomass are scarce, although some research has been developed in Asian countries concerned with the burning of the Indonesian forests in 1997 20,21. In Brazil there are studies that address the burning of sugarcane in the Southeast of the country 22,23 . However this region is not only the most industrialized and densely populated area of the country, but also has a very different climate to that of the Amazon region.

The objective of this study is to assess the association between daily variations in $\mathrm{PM}_{2.5}$ concentrations resulting from the burning of biomass and the daily numbers of children and elderly people hospitalized due to respiratory diseases. The study population included all residents in the municipalities covered by the Regional Health Offices of Alta Floresta and Tangará da Serra, Mato Grosso State, in the Brazilian Amazon in 2005.

\section{Materials and methods}

\section{Study design}

The study was carried out using an ecological design and a time series analytical framework to model the daily counts of hospital admissions for respiratory causes of children and the elderly, measurements of daily concentrations of $\mathrm{PM}_{2.5}$, and meteorological and calendar-related variables.

\section{Study population}

The municipalities of Alta Floresta and Tangará da Serra were selected for the study because they presented the worst indicators of morbidity and mortality due to respiratory diseases amongst children under 5 between 2000 and 200424 .

Aggregated hospital admissions data from the set of municipalities neighboring Alta Floresta and Tangará da Serra, bound to the respective Regional Health Offices, were also used in this study due to the possible displacement of patients seeking care at better hospitals. These two municipalities are the regional references for hospitalization and therefore receive patients through spontaneous demand from neighboring towns, although the patient's place of residence is not always recorded accurately. It is possible that patients living in smaller towns omit this fact in order to facilitate the admission process. Another justification for aggregating the admissions by place of residence in that area is to increase the number of individuals in the study and, consequently, to increase the statistical power. The area of the regional health office of Alta Floresta is shown in Figure 1 and encompasses the municipalities of Alta Floresta, Apiacás, Carlinda, Nova Bandeirantes, Nova Canaã do Norte, Nova Monte Verde, and Paranaíta. These municipalities are located in the extreme north of the state of Mato Grosso and south of the "deforestation arch" of the Brazilian Amazon, covering 58,558 $\mathrm{km}^{2}$ with an estimated population of 101,278 inhabitants during the study period (Secretaria Estadual de Planejameto de Mato Grosso. http://www.sep lan.mt.gov.br), including 10,815 (10.7\%) children under 5 and 3,478 (3.4\%) people over 64 .

The area of the regional health office of Tangará da Serra comprises the municipalities of Arenápolis, Barra do Bugre, Brasnorte, Campo Novo dos Parecis, Denise, Nova Marilândia, Nova Olímpia, Porto Estrela, Santo Afonso, and Sapezal. One main economic activity in the area is sugarcane production with around $65 \%$ of output being manually cut, then burned. It is estimated that approximately 90,000 hectares of 
Figura 1

The municipalities of Alta Floresta and Tangará da Serra, Mato Grosso State, subequatorial Amazon, Brazil.

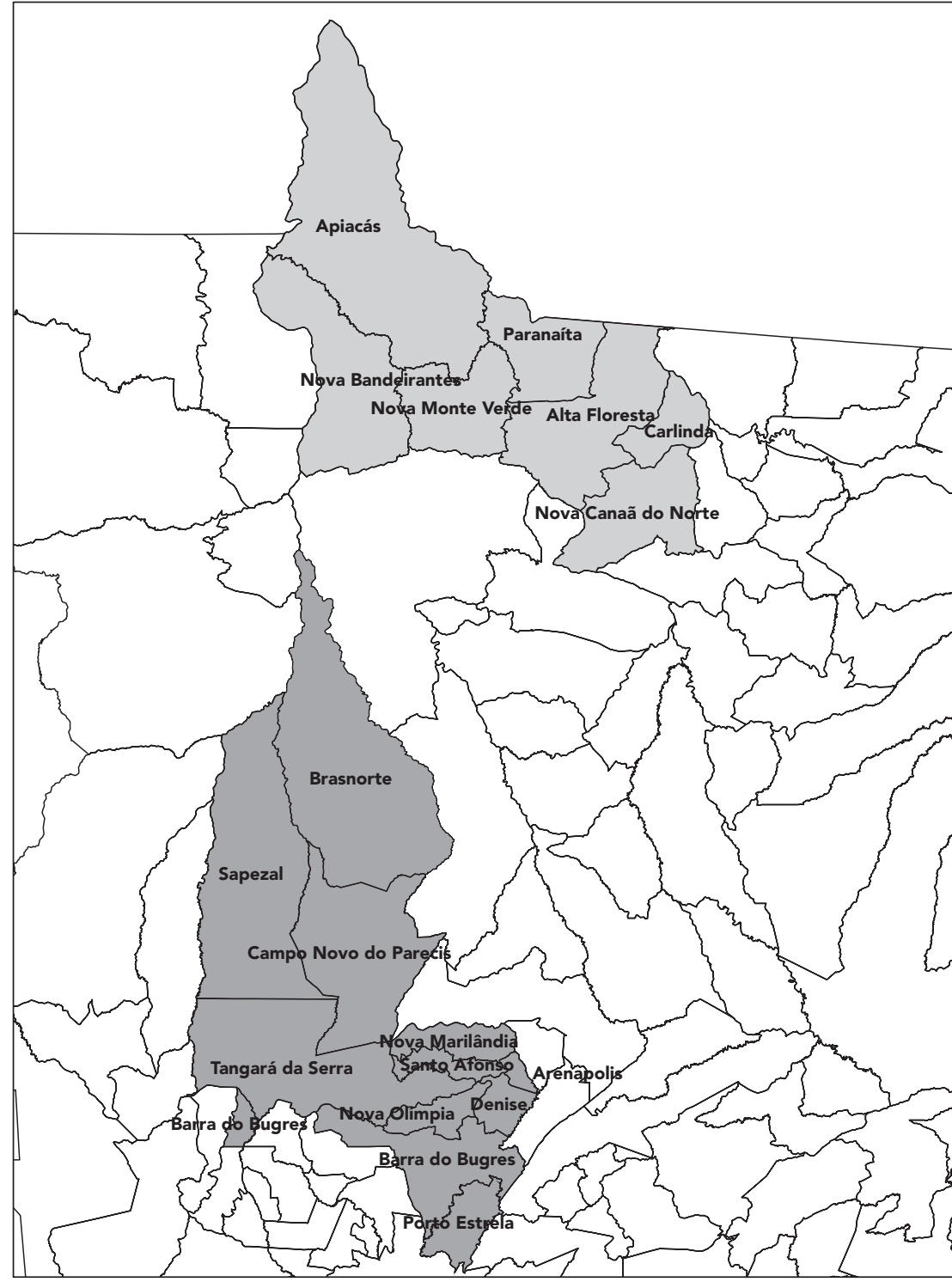

$0 \quad 40 \quad 80$

एᄆ $\square$
160$$
160
$$$$
240
$$

320

Regional Health Office Alta Floresta

Regional Health Office Tangará da Serra

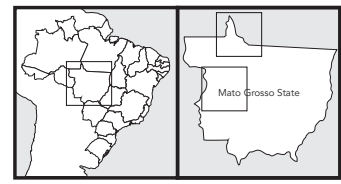


sugarcane are burned every year (http://www.se plan.mt.gov.br). These municipalities occupy an area of $66,262 \mathrm{~km}^{2}$, with an estimated population of 198,984 inhabitants during the study period (Brazilian Institute of Geography and Statistics. 2000 Demographic Census. http:/ / www.ibge.gov. br), including 21,991 (11\%) under five year olds and 6,204 (3\%) over 64 year olds.

The dispersion patterns of $\mathrm{PM}_{2.5}$ hardly vary across the municipalities of Alta Floresta and Tangará da Serra, meaning that misclassification of exposure should not occur due to aggregation of the municipalities. As regards the exposure investigated in this study, it is known that $\mathrm{PM}_{2.5}$ remains in the atmosphere for a relatively long period of time (around 2 weeks) due to the reduced weight and size of the particulates 25 .

\section{Data source and management}

Hospital admission (outcome) data were obtained from the database of the Hospital Information System within the Unified National Health System (SIH-SUS) for all non-elective hospital admissions of children under five and elderly people over 64 , which occurred during the period 1 January to 31 December 2005 (http:/ / www. datasus.gov.br). The analysis concerns hospital admissions for all causes in chapter X (J00 to J99) of the $10^{\text {th }}$ revision of the International Classification of Diseases (CID-10) 26. Due to municipalities having small population sizes and, therefore, low counts of hospital admissions it was not possible to analyze specific causes.

Daily measurements of $\mathrm{PM}_{2.5}$ were estimated by means of the Coupled Aerosol and Trace Gases Transport Model for the Brazilian Development of the Regional Atmospheric Modeling System (CATT-BRAMS) 27 developed at the National Center for Weather Forecasting and Climate Studies, National Institute for Space Research (CPTEC/ INPE). The model provides $\mathrm{PM}_{2.5}$ measurements every three hours over a grid of $30 \times 30 \mathrm{~km}^{2}$ cells. Daily arithmetic averages of concentrations of fine particulate matter were calculated based on the averages of the set of cells which make up the territorial area of the municipalities under investigation.

Daily meteorological information regarding the temperature and relative air humidity were obtained from the Brazilian Airport Authority (INFRAERO) weather station located in Alta Floresta and from the National Meteorological Institute (INMET) automatic station located in Tangará da Serra.

\section{Data analysis}

The analyses were performed for the whole year as well as restricted to the dry season, from July to November, for both age groups. It is known that the fires begin after a few days without rain and continue for approximately one month after the start of the rainy season, while rainfall is still sparse. That is why the so-called "dry season" in this study refers to the period in which, as well as being less humid, also has frequent readings (over $50 \%$ of the days) of average daily levels of air pollution over $25 \mu \mathrm{g} / \mathrm{m}^{3}$, from 1 July to 30 November 2005 (153 days).

The daily number of hospital admissions for respiratory diseases was considered as the outcome variable and the average daily levels of $\mathrm{PM}_{2.5}$ were analyzed as the main exposure. Calendar effects were accounted for by means of indicator variables for the days of the week and holidays. However they showed to be non-significant. The number of days passed since the start of the study was used to adjust for the temporal trend and seasonality by means of smooth functions. Furthermore, smooth functions of temperature and relative air humidity were used in order to account for the non-linearity of meteorological variables. Generalized additive models with Poisson errors 28,29 were used to estimate the association between $\mathrm{PM}_{2.5}$ exposure levels and hospital admissions for respiratory diseases in children and elderly people. This particular class of models was used in order to properly account for non-linearity of the time series components and meteorological variables. Likelihood ratio testing showed that the non-linearity hypothesis holds. The linear effects of the pollutants were estimated for the same day and up to one week before the outcome and moving averages of up to 15 days. The latter represent accumulated exposure on the days before the outcome. Decisions about variables kept in the model as well as the degrees of freedom for the non-linear terms were based on the usual diagnostics for regression analysis of time series data, e.g. periodogram, partial autocorrelation function, and the quantile plotting of standardized deviance residuals.

The results were expressed in terms of the percentage increase in hospital admission rates for respiratory diseases per additional $10 \mu \mathrm{g} / \mathrm{m}^{3}$ in the estimated mean of $\mathrm{PM}_{2.5}$ concentrations, and respective $95 \%$ confidence intervals $(95 \% \mathrm{CI})$. The analyses were carried out by means of the ares library ${ }^{30}$, a home tailored collection of routines for data analysis of time series of air pollution in the software R version 2.8.1 (The R Foundation for Statistical Computing, Vienna, Austria; http:// www.r-project.org). 


\section{Results}

In 2005 there were 481 children and 365 elderly hospital admissions due to respiratory diseases, with a daily average of 1.3 and 1.0 respectively, in the Alta Floresta region. In Tangará da Serra 1,897 children and 403 elderly people were hospitalized with such diseases, with a daily average of 5.2 and 1.1, respectively. As regards the average daily $\mathrm{PM}_{2.5}$ levels, in Alta Floresta during the dry season an average of $44.5 \mu \mathrm{g} / \mathrm{m}^{3}\left( \pm 39 \mu \mathrm{g} / \mathrm{m}^{3}\right)$ was registered, with a maximum of $257.5 \mu \mathrm{g} / \mathrm{m}^{3}$. In Tangará da Serra the average daily $\mathrm{PM}_{2.5}$ measurement was $30.6 \mu \mathrm{g} / \mathrm{m}^{3}\left( \pm 28.6 \mu \mathrm{g} / \mathrm{m}^{3}\right)$ and the maximum, $209.9 \mu \mathrm{g} / \mathrm{m}^{3}$. Minor variations in the average temperature of Alta Floresta and Tangará da Serra were observed with sporadic days of temperature drops, more significantly in Tangará da Serra. These regions present an average temperature of $28^{\circ} \mathrm{C}\left(22\right.$ to $36^{\circ} \mathrm{C}$ ) and $25^{\circ} \mathrm{C}$ ( 14 to $30^{\circ} \mathrm{C}$ ), respectively. As regards relative air humidity, similar measurements were verified between the two sites studied, with daily averages of 60 to $70 \%$. However, during the dry season the Alta Floresta region presented a minimum of $15 \%$, whereas in Tangará da Serra the minimum was $29 \%$ (Table 1).

Figure 2 shows the typical reduction in relative air humidity during the dry season. It begins in the month of May, with the lowest levels recorded in the month of August. Both Alta Floresta and Tangará da Serra present some days of temperature drops mainly between July and October the dry season as described above. The average $\mathrm{PM}_{2.5}$ levels are higher between the months of August and October. However, the emissions in Tangará da Serra begin in the month of May, two months before those registered in the Alta Floresta region.

Descriptive analysis of the variables: number of hospital admissions for children and the elderly by respiratory disease, temperature, humidity and $\mathrm{PM} 2.5$. Alta Floresta and Tangará da Serra, Mato Grosso State, Brazil, 2005

\begin{tabular}{|c|c|c|c|c|c|c|}
\hline & Average (SD) & Minimum & $\mathrm{P} 25$ & P50 & P75 & Maximum \\
\hline \multicolumn{7}{|l|}{ Alta Floresta } \\
\hline \multicolumn{7}{|l|}{ Whole period 2005} \\
\hline Respiratory disease admissions $<5$ years old & $1.32(1.25)$ & 0.00 & 0.00 & 1.00 & 2.00 & 6.00 \\
\hline Respiratory disease admissions $<65$ years old & $1.00(1.09)$ & 0.00 & 0.00 & 1.00 & 2.00 & 5.00 \\
\hline Temperature $\left({ }^{\circ} \mathrm{C}\right)$ & $27.5(2.16)$ & 21.70 & 26.20 & 27.80 & 28.90 & 36.30 \\
\hline Humidity (\%) & $68.3(14.18)$ & 15.44 & 59.58 & 67.77 & 78.30 & 97.78 \\
\hline $\mathrm{PM}_{2.5}\left(\mu \mathrm{g} / \mathrm{m}^{3}\right)$ & $20.4(32.58)$ & 0.00 & 2.07 & 5.22 & 26.64 & 257.45 \\
\hline \multicolumn{7}{|l|}{ Dry season 2005} \\
\hline Respiratory disease admissions $<5$ years old & $1.35(1.19)$ & 0.00 & 0.00 & 1.00 & 2.00 & 5.00 \\
\hline Respiratory disease admissions $<65$ years old & $0.97(1.12)$ & 0.00 & 0.00 & 1.00 & 2.00 & 5.00 \\
\hline Temperature $\left({ }^{\circ} \mathrm{C}\right)$ & $27.96(2.39)$ & 21.70 & 26.9 & 28.20 & 29.40 & 36.30 \\
\hline Humidity (\%) & $60.15(13.95)$ & 15.44 & 50.8 & 60.64 & 68.13 & 94.76 \\
\hline $\mathrm{PM}_{2.5}\left(\mu \mathrm{g} / \mathrm{m}^{3}\right)$ & 44.49 (39.09) & 0.00 & 18.20 & 31.91 & 61.75 & 257.45 \\
\hline \multicolumn{7}{|l|}{ Tangará da Serra } \\
\hline \multicolumn{7}{|l|}{ Whole period 2005} \\
\hline Respiratory disease admissions $<5$ years old & $5.20(3.64)$ & 0.00 & 2.00 & 5.00 & 7.00 & 19.00 \\
\hline Respiratory disease admissions $<65$ years old & $1.10(1.09)$ & 0.00 & 0.00 & 1.00 & 2.00 & 7.00 \\
\hline Temperature $\left({ }^{\circ} \mathrm{C}\right)$ & $24.68(2.71)$ & 13.66 & 24.04 & 25.21 & 26.24 & 29.65 \\
\hline Humidity (\%) & $71.47(15.29)$ & 28.73 & 60.67 & 76.27 & 84.10 & 94.56 \\
\hline $\mathrm{PM}_{2.5}\left(\mu \mathrm{g} / \mathrm{m}^{3}\right)$ & $17.19(22.84)$ & 0.00 & 3.61 & 8.72 & 21.24 & 209.87 \\
\hline \multicolumn{7}{|l|}{ Dry season 2005} \\
\hline Respiratory disease admissions $<5$ years old & $4.77(3.11)$ & 0.00 & 2.00 & 5.00 & 7.00 & 18.00 \\
\hline Respiratory disease admissions $<65$ years old & $1.09(1.01)$ & 0.00 & 0.00 & 1.00 & 2.00 & 4.00 \\
\hline Temperature $\left({ }^{\circ} \mathrm{C}\right)$ & $24.70(3.48)$ & 13.66 & 23.62 & 25.60 & 26.93 & 29.65 \\
\hline Humidity (\%) & $62.08(16.01)$ & 28.73 & 48.83 & 63.44 & 75.65 & 94.56 \\
\hline $\mathrm{PM}_{2.5}\left(\mu \mathrm{g} / \mathrm{m}^{3}\right)$ & $30.63(28.56)$ & 0.00 & 13.26 & 22.19 & 41.41 & 209.87 \\
\hline
\end{tabular}


Figura 2

Time evolution of humidity, temperature, and $\mathrm{PM}_{2.5}$ included in the study of the (a) Alta Floresta and (b) Tangará da Serra region. Mato Grosso State, Brazil, 2005.

2a)
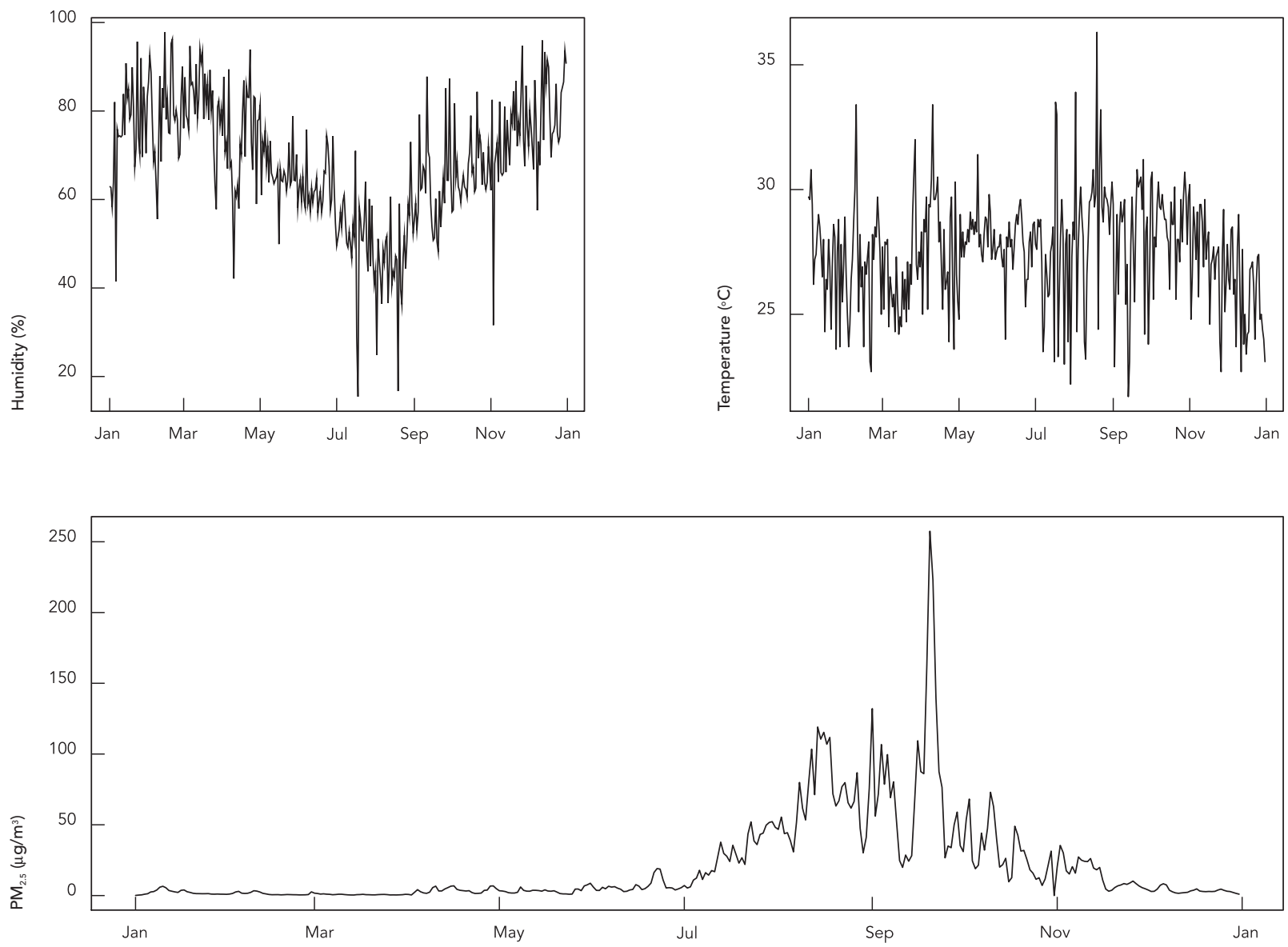

(continues)

Figure 3 presents the percentage increases in the number of hospital admissions for respiratory diseases in children for the year 2005 and for the dry season of 2005, with a lag period of up to 7 days and accumulated effects of up to 15 days (moving averages) for each $10 \mu \mathrm{g} / \mathrm{m}^{3}$ increase in $\mathrm{PM}_{2.5}$ concentration in the Alta Floresta region. Significant values are observed for the whole year and for the dry season with 3 and 4-day lags. For the whole year, the increased risk for a 3-day lag was $4.7 \%$ (95\%CI: $0.6-9.1)$ and for 4 days it was $4.2 \%$ (95\%CI: $0.1-8.5$ ). In the dry season these estimates reach $6 \%$ (95\%CI: $1.4-10.8)$ and $5.1 \%$ (95\%CI: 0.6-9.8) respectively.
For accumulated exposure there were no associations ascertained for the series which covers the whole year. In the dry season a trend of increased risk for up to 12 days was verified. However, the associations were only significant for moving averages of 3 to 5 days. For the moving average of 3 days, the increased risk was $6.8 \%$ (95\%CI: $0.56-13.3)$; for 4 days $7.8 \%$ (95\%CI: 1.3 14.5); and for 5 days 7.5\% (95\%CI: 0.6-14.9).

Figure 4 presents the percentage increases in the number of hospital admissions for respiratory diseases in elderly people for the year 2005 in the Alta Floresta region. Significant values are observed for the whole year for exposure on the concurrent day and with lags of 4, 5 and 6 days. 
2b)
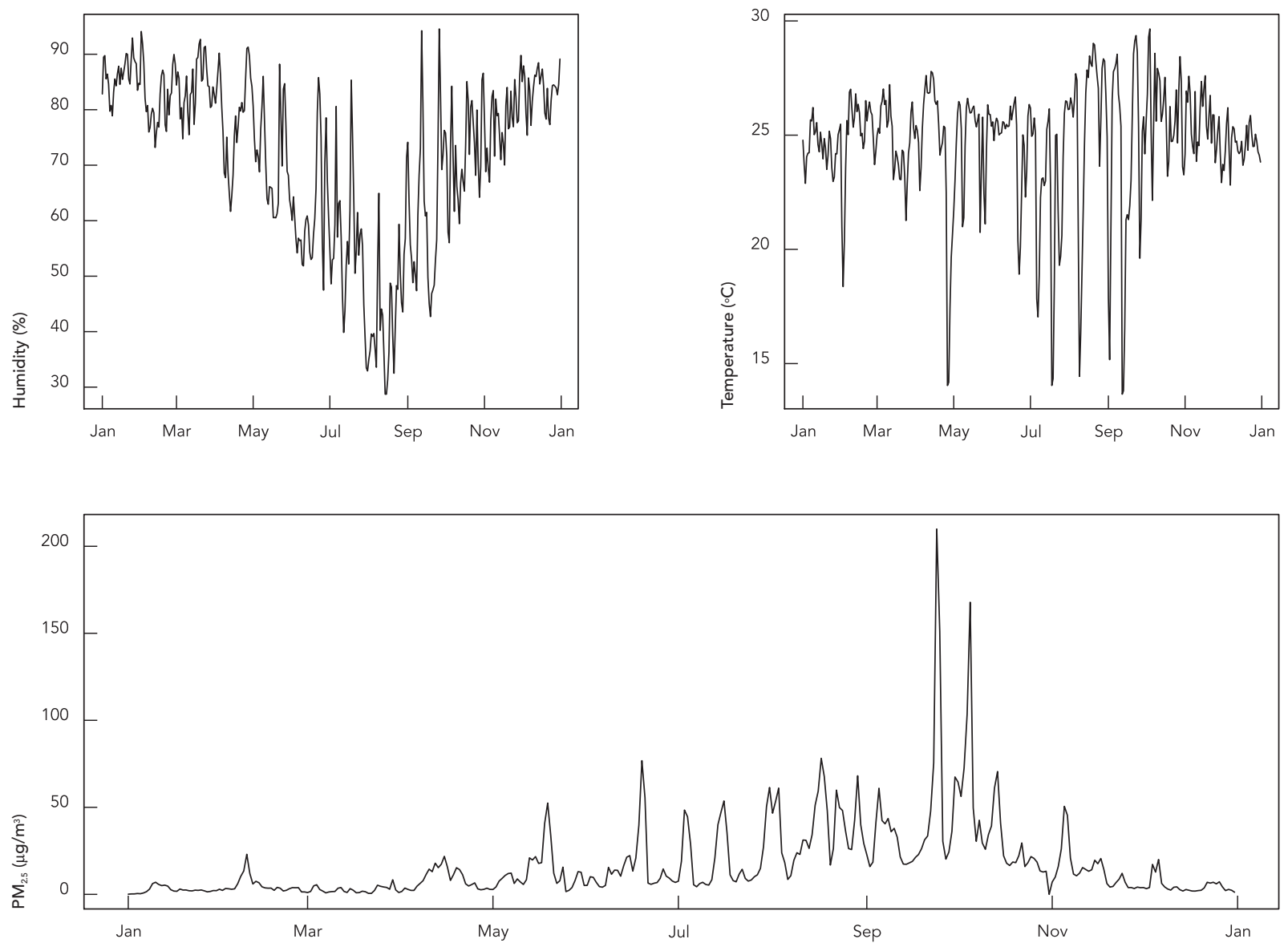

For the actual day, the increased relative risk is $4.3 \%$ (95\%CI: $0.25-8.6$ ); for a 4 -day lag it is $5.5 \%$ (95\%CI: $0.56-10.6)$ for increases of $10 \mu \mathrm{g} / \mathrm{m}^{3}$ of $\mathrm{PM}_{2.5}$. In the analyses of the accumulated effects according to moving averages, significant associations were ascertained with lag periods of 4,5 , 6,8 and 9 days with a percentage increase of the relative risk ranging from 5.5 to $4.1 \%$ in the 4 and 6-day lags, respectively. The upper limit of the confidence intervals for single lag analyses was $9.8 \%$ and for moving averages $10.6 \%$.

In the analyses of the dry season, significant associations were only ascertained for the current day with an increased relative risk of $6.8 \%$ (95\%CI: 0.5-13.5) for each additional $10 \mu \mathrm{g} / \mathrm{m}^{3}$ of $\mathrm{PM}_{2.5}$.

The analyses performed for Tangará da Serra did not show any association between variations in the $\mathrm{PM}_{2.5}$ levels and the number of hospital admissions for respiratory diseases in children and elderly people using single lag or moving average models.

\section{Discussion}

The burning of vegetation that traditionally occurs in the Amazon as part of the deforestation process has an adverse effect on human health. The population living in the Alta Floresta region has been exposed to high levels of air pollution since the early 1990s during the dry season. The associations verified in this study refer to an increased risk of roughly $7 \%$ in the daily number of hospital admissions of children and elderly people for an additional $10 \mu \mathrm{g} / \mathrm{m}^{3}$ of $\mathrm{PM}_{2.5}$. How- 
Figura 3

Percentage increase in the relative risk and $95 \%$ confidence interval in the number of hospital admissions for respiratory diseases in children for the year 2005 ( $a$; c) and the dry season of 2005 (b; d) with a single lag period of up to 7 days and accumulated effects of up to 15 days (moving averages) for a $10 \mu \mathrm{g} / \mathrm{m}^{3}$ increase in the $\mathrm{PM}_{2.5}$ concentration in the Alta Floresta region. Mato Grosso State, Brazil, 2005.

3a)

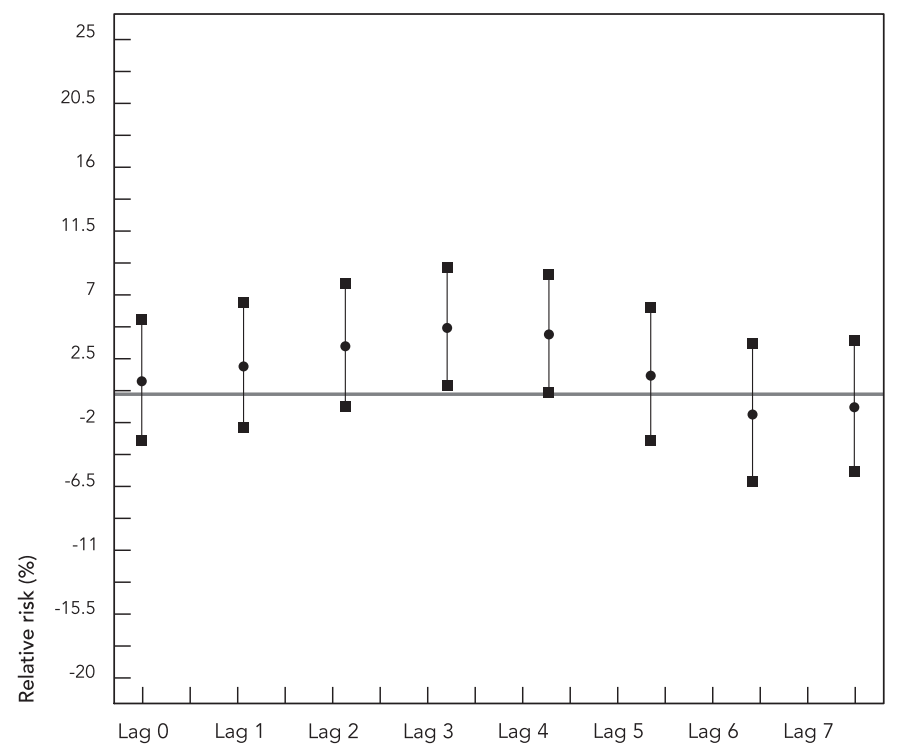

Exposure pollutant: PM

3b)

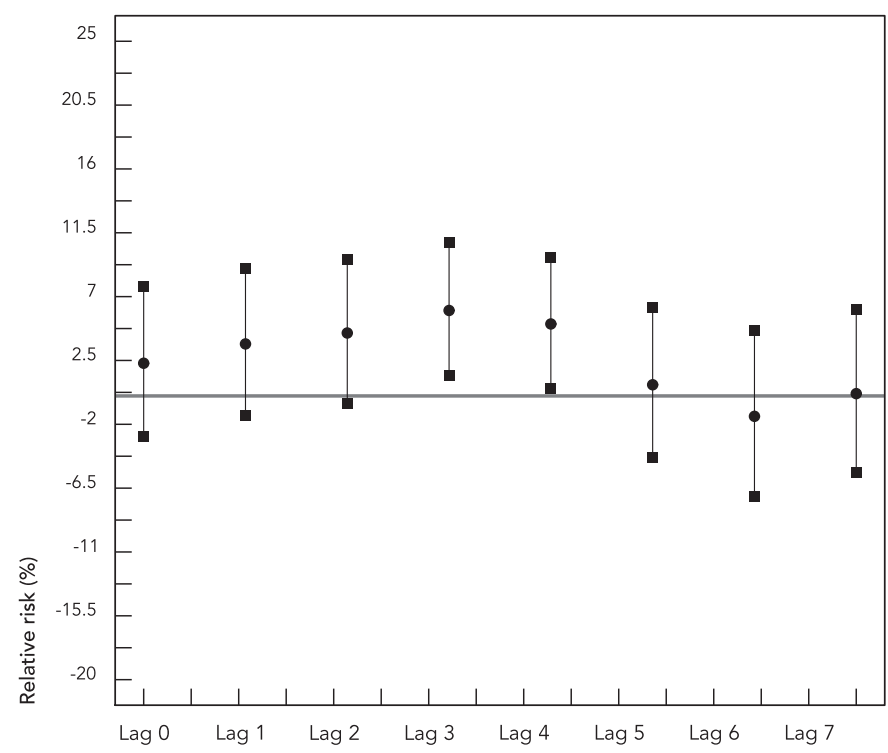

Exposure pollutant: PM

(continues) 
3c)

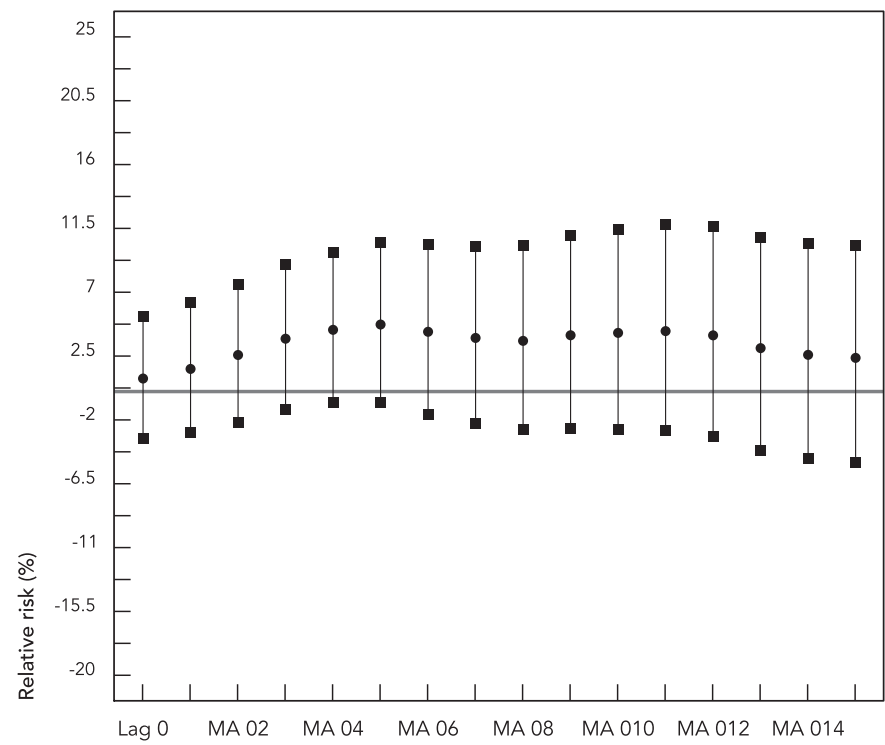

Exposure pollutant: PM

3d)

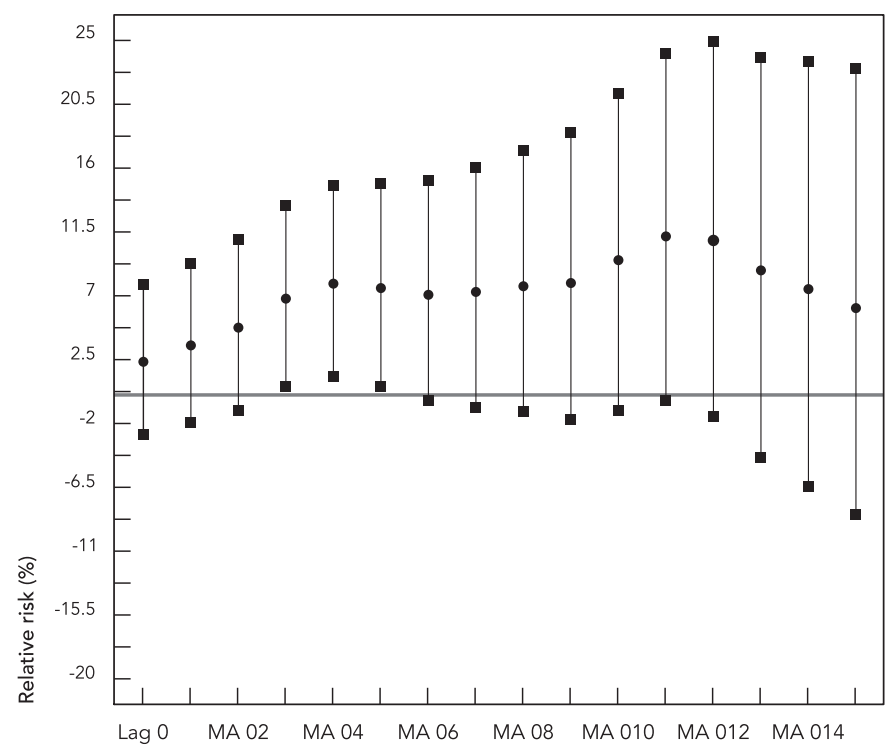

Exposure pollutant: PM 
Figura 4

Percentage increase of relative risk and $95 \%$ confidence interval in the number of hospital admissions for respiratory diseases in elderly people for the year 2005 (a; c) and the dry season of 2005 (b; d) with a single lag period of up to 7 days and accumulated effects of up to 15 days (moving averages) for a $10 \mu \mathrm{g} / \mathrm{m}^{3}$ increase in the $\mathrm{PM}_{2.5}$ concentration in the Alta Floresta region. Mato Grosso State, Brazil, 2005.

4a)

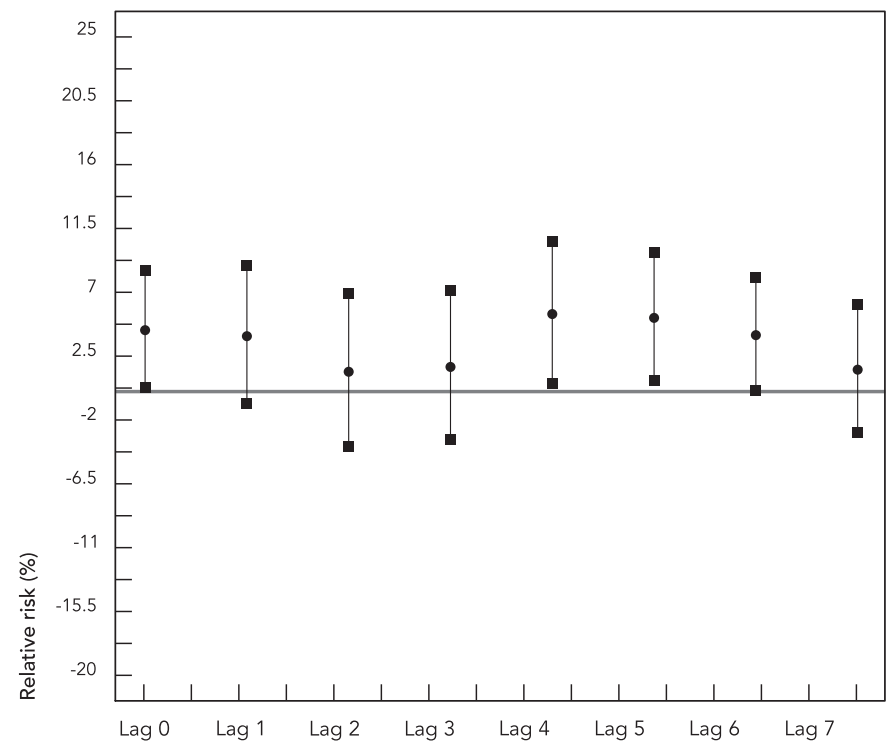

Exposure pollutant: PM

4b)

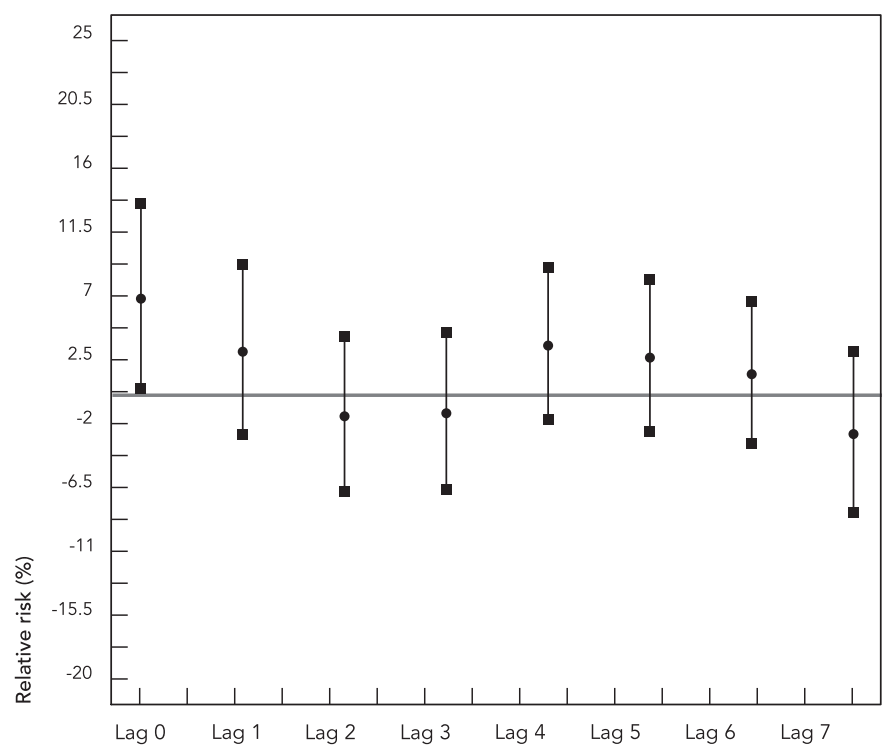

Exposure pollutant: PM

(continues) 
4c)

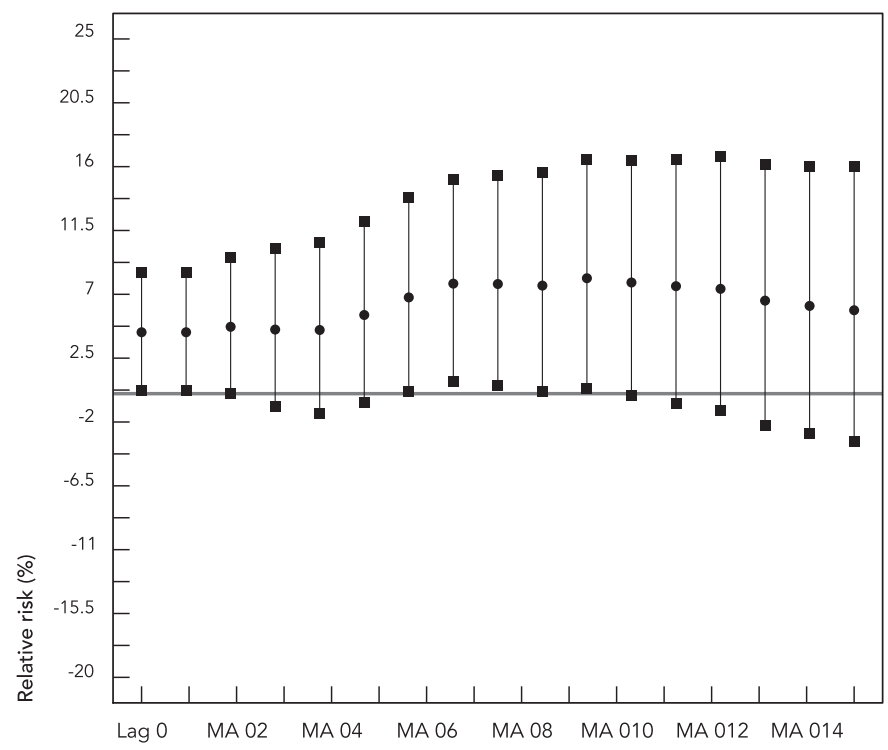

Exposure pollutant: PM

4d)

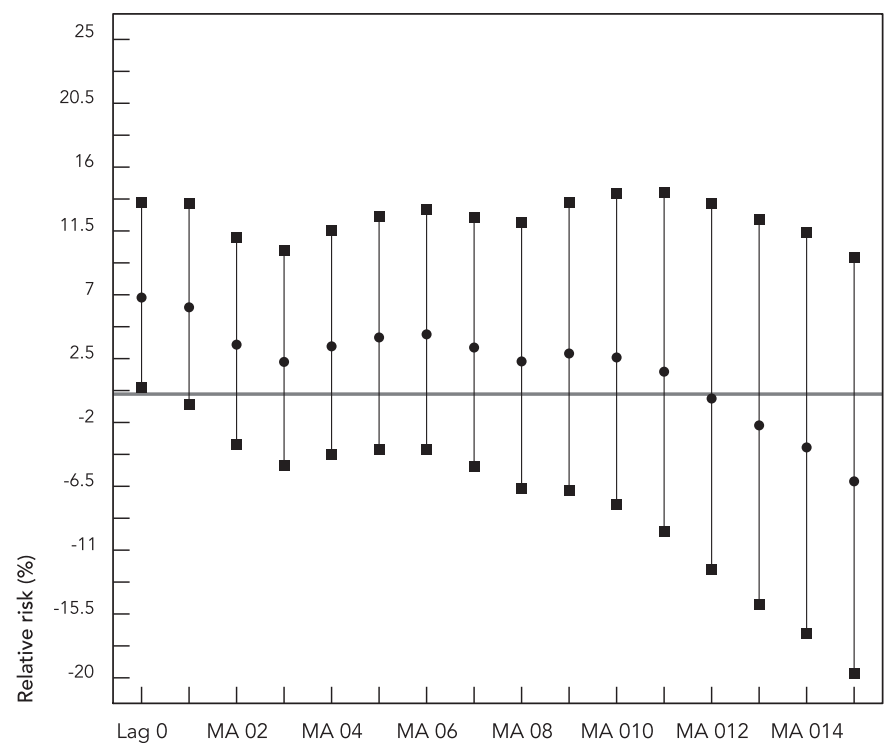

Exposure pollutant: PM 
ever, it is known that during the studied period frequent daily variations ranging from 50 to $90 \mu \mathrm{g} / \mathrm{m}^{3}$ of $\mathrm{PM}_{2.5}$ were registered. Considering the linearity assumed between exposure and the outcome, one can say that the percentage increase in the risk of hospital admissions for respiratory diseases in children and elderly people frequently reached values between 45 to $63 \%$.

The associations ascertained between accumulated exposure to $\mathrm{PM}_{2.5}$ of 3 to 5 days and hospital admissions of children can be explained by the possible differences in the resilience of the respiratory apparatus between the two age groups studied. When exposed to increased concentrations of atmospheric pollutants, children spontaneously suffer a reduced lung function of up to $0.51 / \mathrm{min}$ at that site 31 . Other children may present clinical symptoms of respiratory injuries leading to an increased demand for primary health care. On the other hand, in elderly people the effects of exposure become immediately apparent, resulting in hospitalizations on the same day as the variation in the exposure levels. Elderly people aged over 64 may present chronic changes in the respiratory system due to exposure to tobacco and/or preexisting diseases 4.

In Alta Floresta, primary health care services through the public Family Health Program (FHP) cover $85 \%$ of the population in the urban area and $75 \%$ across the entire municipality. These services give priority to pediatric care (Secretaria Municipal de Saúde de Alta Floresta. http:/ /www. altafloresta.mt.gov.br/secretarias/ver/?act=13). It is possible that this priority leads to the lower number of patients who require hospitalization and the increased lag period in hospital admissions for this age group. In absolute terms, the frequency of child admissions is practically the same as that of the elderly.

The lack of association between the $\mathrm{PM}_{2.5}$ levels and hospital admissions for respiratory diseases in Tangará da Serra may be the result of lower exposure levels when compared to those estimated for Alta Floresta. The daily average $\mathrm{PM}_{2.5}$ level estimated for the region of Tangará da Serra during the dry season of 2005 was $30.6 \mu \mathrm{g} / \mathrm{m}^{3}$, while in Alta Floresta it was $44.5 \mu \mathrm{g} / \mathrm{m}^{3}$.

Beyond of the lower exposure to $\mathrm{PM}_{2.5}$ to which the population of Tangará da Serra was subjected, Rosa et al. 12 verified that hospital admissions of children in this location are influenced by the kind of health care management, which allows hospital services to be outsourced by the public health system. This kind of management allows the priorities of hospital services to be distorted. Tangará da Serra presents an annual number of hospital admissions for pneumonia in children that is 13 times greater than the expected number, according to Pan-American Health Organization (PAHO) standards 12. Nevertheless, even if this hypothesis is valid for children, it would still not suffice to explain the lack of any association between $\mathrm{PM}_{2.5}$ and hospital admissions for respiratory diseases in elderly people.

Brunekreef \& Holgate 32 remark that there is no clear existence of any threshold of $\mathrm{PM}_{2.5}$ exposure up to which it is not detrimental to human health. Emmanuel 21 found increased outpatient care and hospital admissions for respiratory diseases in the general population for $\mathrm{PM}_{2.5}$ exposure peaks of $120 \mu \mathrm{g} / \mathrm{m}^{3}$ in Singapore as a result of forest fires in Indonesia, over $500 \mathrm{~km}$ away. In Brazil, studies concerning the effects of pollution derived from the burning of biomass have been conducted in the sugarcane production areas in the Southeast of the country. Cançado et al. 23 ascertained a $21.4 \%$ increase in hospital admissions of children and elderly people for an additional $10 \mu \mathrm{g} / \mathrm{m}^{3}$ of $\mathrm{PM}_{2.5}$ with a daily average of $22.8 \mu \mathrm{g} / \mathrm{m}^{3}$. According to the World Health Organization (WHO) ${ }^{3}, \mathrm{PM}_{2.5}$ levels above a daily average of $25 \mu \mathrm{g} / \mathrm{m}^{3}$ are harmful to health. Studies carried out in São Paulo 7 and Rio de Janeiro ${ }^{8}$, Brazil, present results of association between $\mathrm{PM}_{10}$, among other pollutants, and the effects on health in terms of morbidity and mortality. If we consider that up to $70 \%$ of $\mathrm{PM}_{10}$ is represented by fine particulates, for São Paulo a daily average of $46,5 \mu \mathrm{g} / \mathrm{m}^{3}$ of $\mathrm{PM}_{2.5}$ is estimated for the period 1993 to 1997 7, a value even higher than those verified in Alta Floresta.

The levels of outdoor pollution bring frequent criticisms of studies which assess the effects of atmospheric pollutants on human health, because in the majority of areas studied most people spend most of the time indoors 32 . Another important criticism results from pollution measurements not being made at the individual level ${ }^{29}$. In this study, neither of these criticisms would seem relevant because this area is characterized by a hot and humid climate and homes or workplaces are usually open, with large windows or balconies. During the day and even in the early evening, children play out in the yards and streets. Furthermore, as the study refers to fine particulate matter resulting from burning biomass located some kilometers away from the homes, the exposure varies much less at the individual level.

The results of the analyses conducted for the dry season are more consistent than the results for the entire year due to the exposure level in that period. In Mato Grosso there are peaks of hospital admissions for respiratory diseases in children at the end of the rainy season. Rosa et 
al. 12 discuss this increase, suggesting the influence of operational factors such as the hiring of physicians by the public service in the months of February and March, the start of the school term and possibly the presence of more allergenic fungi due to the excessive increase in humidity. When specifying epidemiological time series models in general, and in this study in particular, such factors are not taken into account and, therefore, analysis of the annual series may still involve some uncontrolled effects. Standardized residual analysis could reveal problems in the model specification; however it is possible that the general residual diagnosis is considered satisfactory even with the omission of important factors on the linear predictor.

The use of exposure data estimated by modeling is presented as an important tool in monitoring the air quality in the Brazilian Amazon region, where emissions are largely a result of biomass burning. Taking as a reference the whole Amazon area of roughly 6 million $\mathrm{km}^{2}$, it would be logistically and financially unfeasible to track the air quality of this region through ground level monitors. However, the need to aggregate the average exposure data of this study may lead to a smoothing of the $\mathrm{PM}_{2.5}$ levels. The use of aggregate average data according to health care regions could possibly result in underestimated risks.

In this study, the effects of biomass burning were analyzed regarding hospital admissions only for treating respiratory diseases. It is known that the impacts of pollution range from subclinical effects to increased mortality through a variety of injuries ${ }^{4}$. Added to the effects on human health, there is the influence that fires in the Brazilian Amazon have on climate change due to the production of greenhouse gases 33 , as well as immediate losses in the ecosystem which have been widely described in the literature 34 .

In conclusion, the $\mathrm{PM}_{2.5}$ generated by the burning of biomass in the Amazon does have an impact on people's health, with increased hospital admissions for respiratory diseases in children and the elderly. Short-term as well as long-term effects of $\mathrm{PM}_{2.5}$ exposure on mortality in the Amazon region are to be investigated in future studies.

\section{Resumo}

Avaliar o efeito da variação diária nas concentrações de $P M_{2.5}$ da queima de biomassa sobre o número diário de hospitalizações de crianças e idosos por doenças respiratórias, em Alta Floresta e Tangará da Serra, Amazônia brasileira, em 2005. Estudo ecológico de séries temporais de hospitalizações por doenças respiratórias de crianças e de idosos, estimativas de concentrações diárias de $P M_{2.5}$, variáveis meteorológicas e de calendário. Para Alta Floresta os aumentos percentuais do risco relativo (\%RR) de internações por doenças respiratórias em crianças foram significantes para o ano todo e para o período de seca, com defasagens de 3-4 dias. No período de seca o incremento é de 6\% (IC95\%: 1,4-10,8). Para médias móveis de 3-5 dias as associações mostraram-se significantes. O \%RR para idosos foram significantes para o dia corrente na seca com 6,8\% (IC95\%: 0,5-13,5) de incremento para aumento de $10 \mu \mathrm{g} / \mathrm{m}^{3}$ de $\mathrm{PM}_{2.5}$. Não foram verificadas associações para Tangara da Serra. As emissões de $\mathrm{PM}_{2.5}$ pela queima de biomassa na Amazônia aumentaram as hospitalizações por doenças respiratórias de crianças e idosos

Doenças Respiratórias; Hospitalização; Poluição do Ar 


\section{Contributors}

E. Ignotti, W. L. Junger and A. C. M. Ponce de Leon were responsible for data analysis and writing the article. S. S. Hacon coordinated the research and helped to write the article. D. Mourão organized the database and contributed in the article write up. K. Longo and S. Freitas were responsible for the estimates for environmental data and for contributing to the article. P. Artaxo participated in the article write up.

\section{Acknowledgments}

The present study complements the INCT of Climate Change and REDECLIMA Project FINEP 01.08.0405.01. It was partially supported by SISAM "Sistema de Informações Ambientais Integrado à Saúde Ambiental" Project 030LIV08 betwen FIOTEC, INPE, CGVAM/SVS/MS, and the PPSUS/FAPEMAT.

\section{References}

1. Fearnside PM. Homem e ambiente na Amazônia. In: Fearnside PM, organizador. A Floresta Amazônica nas mudanças globais. Manaus: Editora do Instituto Nacional de Pesquisas da Amazônia 2003. p. 1-18.

2. Instituto Brasileiro do Meio Ambiente e dos Recursos Naturais Renováveis. Queimadas - vegetation fires. http://www.dpi.inpe.br/proarco/bdqueima das/ajuda1.html (accessed on 22/Feb/2007).

3. World Health Organization Regional Office for $\mathrm{Eu}$ rope. Air quality guidelines. Global update 2005. Copenhagen: World Health Organization Regional Office for Europe; 2005.

4. Pope CA, Dockery DW. Health effects of fine particulate air pollution: lines that connect. J Air Waste Manage Assoc 2006; 56:709-42.

5. Samet JM, Dominici F, Curriero FC, Coursac I, Zeger SL. Fine particulate air pollution and mortality in 20 U.S. cities, 1987-1994. N Engl J Med 2000; 343:1742-9.

6. Atkinson RW, Anderson HR, Sunyer J, Ayres J, Baccini M, Vonk JM, et al. Acute effects of particulate air pollution on respiratory admissions: results from APHEA 2 Project. Am J Respir Crit Care Med 2001; 164:1860-6.
7. Freitas C, Bremner SA, Gouveia N, Pereira LAA, Saldiva PHN. Hospital admissions and mortality: association with air pollution in São Paulo, Brazil, 1993 to 1997. Rev Saúde Pública 2004; 38:751-7.

8. Ministério do Meio Ambiente. Qualidade do ar e efeito na saúde da população do município do Rio de Janeiro. Relatório de conclusão: Programa AreSRio. Brasília: Ministério do Meio Ambiente; 2005.

9. Ostro B, Broadwin R, Green S, Feng W-Y, Lipsett M. Fine particulate air pollution and mortality in nine California counties: results from CALFINE. Environ Health Perspect 2006; 114:29-33.

10. Cakmak S, Dales RE, Vidal CB. Air pollution and mortality in Chile: susceptibility among the elderly. Environ Health Perspect 2007; 115:524-7.

11. Ignotti E, Hacon SS, Silva AMC, Junger WL, Castro HA. Efeitos das queimadas na Amazônia: método de seleção dos municípios segundo indicadores de saúde. Rev Bras Epidemiol 2007; 10:453-64.

12. Rosa AM, Ignotti E, Hacon SS, Castro HA. Analysis of hospitalizations for respiratory diseases in Tangará da Serra, Brazil. J Bras Pneumol 2008; 34: 575-82. 
13. Mascarenhas MDM, Vieira LC, Lanzieri TM, Leal APPR, Duarte AF, Hatch DL. Poluição atmosférica devido à queima de biomassa florestal e atendimentos de emergência por doença respiratória em Rio Branco, Brasil - setembro, 2005. J Bras Pneumol 2008; 34:42-6.

14. Becker B. Geopolítica da Amazônia. Estud Av 2005; 19:71-86.

15. Yamasoe MA, Artaxo P, Miguel AH, Allen AG. Chemical composition of aerosol particles from direct emissions of biomass burning in the Amazon Basin: water-soluble species and trace elements. Atmos Environ 2000; 34:1641-53.

16. Pope CA, Ezzati M, Dockery D. Fine-particulate air pollution and life expectancy in the United States. N Engl J Med 2009; 360:376-86.

17. Hacon S, Artaxo P, Gerab F, Yamasoe MA, Campos RC, Conti LF, et al. Atmospheric mercury and trace elements in the region of Alta Floresta in the Amazon basin. Water Air Soil Pollut 1995; 80:273-83.

18. Nel A. Air pollution-related illness: effects of particles. Science 2005; 308:804.

19. United States Environmental Protection Agency. Fine particle (PM2.5) designations. http://www. epa.gov/pmdesignations/faq.htm\#0 (accessed on 20/Mar/2009).

20. Aditama TY. Impact of haze from forest fire to respiratory health: Indonesian experience. Respirology 2000; 5:169-74.

21. Emmanuel SC. Impact to lung health of haze from forest fires: the Singapore experience. Respirology 2000; 5:175-82.

22. Arbex MA, Martins LC, Oliveira RC, Pereira LAA, Arbex FF, Cançado JED, et al. Air pollution from biomass burning and asthma hospital admissions in a sugar cane plantation area in Brazil. J Epidemiol Community Health 2007; 61:395-400.

23. Cançado JED, Braga A, Pereira LAA, Arbex MA, Saldiva PHN, Santos UP. Repercussões clínicas da exposição à poluição atmosférica. J Bras Pneumol 2006; 32 Suppl 2:S5-11.

24. Ignotti E, Valente JG, Hacon SS, Longo K, Freitas S, Artaxo P. Impacts of particulate matter (PM2.5) emitted from biomass burning in the Amazon regarding hospital admissions by respiratory diseases: building up environmental indicators and a new methodological approach. Rev Saúde Pública 2010; 44:121-30.
25. Andreae M, Artaxo P, Fischer H, Freitas SR. Grégoire J-M, Hansel A, et al. Transport of biomass burning smoke to the upper troposphere by deep convection in the equatorial region. Geophys Res Lett 2001; 28:951.

26. Organização Mundial da Saúde. Classificação estatística internacional de doenças e problemas relacionados à saúde, 10a revisão. v. 1. São Paulo: Centro Colaborador da OMS para a Classificação de Doenças em Português; 1995.

27. Longo KM, Freitas SR, Setzer A, Prins E, Artaxo P, Andreae MO. The Coupled Aerosol and Tracer Transport model to the Brazilian developments on the Regional Atmospheric Modeling System (CATT-BRAMS). Part 2: model sensitivity to the biomass burning inventories. Atmospheric Chemistry and Physics Discussion 2007; 7:8571-95.

28. Hastie TJ, Tibshirani RJ. Generalized additive model. London: Chapman and Hall; 1990.

29. Dominici F. Time-series analysis of air pollution and mortality: a statistical review. Res Rep Health Eff Inst 2004; (123):3-27.

30. Junger W. Análise, imputação de dados e interfaces computacionais em estudos de séries temporais epidemiológicas [Tese de Doutorado]. Rio de Janeiro: Instituto de Medicina Social, Universidade do Estado do Rio de Janeiro; 2008.

31. Viana LS, Hacon SS, Castro HA, Ignotti E, Artaxo P, Leon ACP. Effect of air pollution on lung function in schoolchildren in Alta Floresta, Mato Grosso, Brazil. In: Annais of EcoHealth: Healthy Environmets, Healthy People. International Forum EcoHealth 2008. México DF: Secretaría de Salud; 2008. p. 86.

32. Brunekreef B, Holgate ST. Air pollution and health. Lancet 2002; 360:1233-42.

33. Bowman DMJS, Balch JK, Artaxo P, Bond WJ, Carlson JM, Cochrane MA, et al. Fire in the Earth system. Science 2009; 324:481-4.

34. Large-Scale Biosphere. Atmosphere experiment in Amazonia. http://daac.ornl.gov/LBA/lba.html (accessed on 20/Mar/2009)

Submitted on $30 / \mathrm{Jul} / 2009$

Final version resubmitted on 14/Dec/2009

Approved on 26/Jan/2010 